\title{
Transformational Leadership Plans
}

\author{
Pedro P Aguas ${ }^{1, *}$, Liliana Valle Zapata $^{1} \&$ Danilsa Lorduy Arellano ${ }^{1}$ \\ ${ }^{1}$ Department of Foreign Languages, University of Cordoba, Montería, Colombia \\ *Correspondence: Department of Foreign Languages, University of Cordoba, Montería, Colombia. Tel: \\ 57-311-406-6622. E-mail: aguaspedro@yahoo.com
}

Received: March 10, 2017

doi:10.5430/wje.v7n4p1
Accepted: July 7, 2017 Online Published: August 6, 2017

URL: https://doi.org/10.5430/wje.v7n4p1

\begin{abstract}
Higher education institutions are aware of the need to incorporate learning-driven assessment artifacts into their doctoral programs to ensure successful leadership development. However, in attempting to integrate learning into students' future performance, it appears that there is no general agreement upon the most effective assignments. The plethora of leadership tasks makes it difficult for scholars and instructors to guarantee that doctoral learners will use their leadership skills in their current or future workplaces. One way to incorporate current learning into professional performance is to translate course learning into personal leadership development plans. This article describes a short-term transformational leadership development plan rooted in the Scholar/Practitioner/ Leader Model, University of Phoenix, U.S.A., educational model. The plan is a culminating learning task of a Transformational Leadership and Innovation course. Upon completion of this course, doctoral learners would be prepared to incorporate the principles of transformational leadership into their leadership plans when completing them in specific academic contexts. The plan proposed defines a strategy for maximizing leadership effectiveness and spells out learning from doctoral courses.
\end{abstract}

Keywords: leadership; personal leadership development plan; strength; weakness

\section{Introduction}

This learning task was completed for a Transformational Leadership and Innovation course. Students in this course were doctoral students in their third-class year of the Doctor of Education in Educational Leadership with a Specialization in Curriculum and Instruction Program at University of Phoenix (UOP). UOP's processes "[i]ncrease awareness of how one communicates as a Scholar/Practitioner/Leader across boundaries" (University of Phoenix, 2012 , p. 2). One of the outcomes of this program is "to [s]upport and enhance the educational process through instructional leadership" (University of Phoenix, 2012, p. 2). The course is a bimester-long (eight weeks) project that culminates in a final paper that incorporates doctoral learning that occurred throughout the bimester.

Transformational leadership is a key factor of innovation (Al-Husseini, Elbeltagi, \& Dosa, 2013). Transformational leadership suggests the interaction between the leader and his or her followers in the pursuit of original goals based on "higher-order needs" identified and acknowledged by both parties (Mulla \& Krishnan, 2011). Effective transformational leadership translates into a dynamic process that involves identifying individuals' identification of opportunities and feelings to respond to emerging patterns conducive to positive change. (Pochron, 2009). Innovation as process represents an educational tool, which contributes to the effective implementation of educational initiatives (Al-Husseini, Elbeltagi, \& Dosa, 2013). "Accordingly, innovation... means accepting, implementing and developing educational process innovation focused on [transformational leadership plans] and performance related pay" (p. 2).

Educational organizations strive to deal with management requirements for the improvement of leadership roles based on personal leadership plans that include concrete steps leading to maximizing learners' leadership effectiveness in their workplace. The experience of one of the authors of this article as the leader of the English Licentiate Program (ELP) at Universidad de Córdoba serves as the empirical support for this article. The proposed plan consists of six steps:

- Making decisions on the basis of current leadership theory, 
- Identifying leadership strengths and weaknesses,

- Designing a plan for making the best use of current strengths and correcting weaknesses,

- Identifying gaps between the current leader and the future leader,

- Implementing specific Action items to close gaps between the current leader and the future leader, and

- Establishing a timeline for implementing each action item in a plan.

\section{Making Decisions on the Basis of Current Leadership Theory}

Some theories or models should be the basis for any leadership behavior, mainly if this behavior results in an implementable set of ideas and procedures. Leadership practices are intended to influence others and transcend the particular context arena and the participation of a single individual who decides to accept huge challenges in life (The Jossey-Bass reader, 2003). Among the paucity of leadership theories, some represent the basis to initiate and construct a clear and robust plan which leaders can implement with potential success. The following theories or models often underpin this transformational leadership project.

\subsection{The Personal Leadership Model and the Scholar/Practitioner/Leader Model}

A personal leadership model derives from the interaction between learners and the learned information provided by scholars, practitioners, active leaders, and the participation of students in a developmental process, which allows them to construct their leadership model throughout the doctoral studies (Beatty, 2014). The scholar/practitioner/leader model (the University of Phoenix educational model) is a combination of different dimensions of scholarship, which allows learners to grow professionally, personally, and as potential leaders. Hence, the model seeks to invent and articulate new knowledge based on empirical data to establish facts. Integration suggests the review of knowledge to construct meaning. The application deals with the use of new knowledge and information in a particular context. Teaching translates into the conveyance of data to other people (Hatfield, 2015).

Personal models in a doctoral course can be grounded on the theoretical assumptions of a scholar/practitioner/leader model because of the active participation of the learner in an interactive process that gradually takes the students from an initial stage to a higher one. The evolutionary nature of the process makes it possible to improve leadership performance through permanent interaction and formative feedback as well as discussion stemmed from current literature on the topic. Doctoral learners' assimilation of the established model can be slow due to the complexity of the issues and the demands of a learning system (i.e., distance learning). Nevertheless, some primary outcomes can be achieved and put into practice in doctoral learners' role as members of an academic division within an educational institution (i.e. a language department).

Doctoral students are future leaders, professionals, and public students (Terry \& Liller, 2014). As future leaders and practitioners, doctoral learners must think of an effective way to use scholarly knowledge to reach a vision and generate change in their institutions. Allen (2002) considers seven roles that help leaders and practitioners to make their work meaningful. They usually involve in the role of (creating meaning, considering the system as a whole, identifying core relationships, considering temporal wisdom, providing a variety of visions of the future, identifying new patterns for education, and moving from own intelligence to collective wisdom. As public learners, they have a clear role to play (Mitra \& Buzzanell, 2017). Buss, Zambo, Zambo, and Williams (2014) stated that “... educational leaders ... are scholarly practitioners, individuals who combined practical wisdom, professional knowledge, and research skills to identify, frame, and solve problems of practice in their workplace settings" (p. 139). Using this approach implies testing one's ideas against those of followers and involving them in our intellectual and scholarly activities. In so doing, a sense of teamwork is created to promote institutional synergy and strengthen leadership skills, not only in the leaders but also in the followers. In sum, doctoral learners' personal leadership model is always in construction, and the scholar/practitioner/leader model continues to bolster the leaders of the future. The current leadership plan represents unequivocal evidence of this assertion.

\subsection{Transformational and Charismatic Leadership}

Transformational and charismatic leaders develop and reach a vision and inspire their followers to participate in the achievement of common and broader goals (Mulla \& Krishnan, 2011; Nahavandi, 2006; Yukl, 2013). ). Success then is contingent on two main factors. First, the leader's capacity to promote and foster change and his ability to influence those around him. Second, the leader's willingness and readiness to motivate followers and his or her concern about their wants and needs. These assumptions contribute the creation of a solid leadership-focused construct that helps leaders and followers to design and implement effective personal plans. 


\subsection{Situational Leadership}

According to this theory, "there is no one-size-fits-all approach to leadership, but rather that successful leaders are flexible and adapt their style to suit the situation ("Situational Leadership Theory", 2015, p. 1). This theory was introduced by Paul Hersey and Ken Blanchard, who proposed the Life Cycle of Leadership and represents the first generation of situational leadership theory (Graeff, 1997; Thompson \& Glasø, 2015). The two authors posited that leaders adapt their behaviors to followers' levels of maturity when performing a task.

The second generation of the same theory emphasizes the leader's behavior on followers (The Jossey-Bass reader, 2003; Thompson \& Glasø, 2015). It involves task behavior, according to which leaders spell out individuals and group's responsibilities and duties. It also refers to relationship behavior. In this respect, leaders establish effective communication channels with their followers. Leadership is situational because the leader's effectiveness is contingent on the situation (Nahavandi, 2006, Yukl, 2013). Subordination translates into high-level maturity, and low-level maturity and the accomplishment of tasks are contingent on the followers' levels of readiness, i.e., willingness, commitment, confidence, and motivation (The Jossey-Bass reader, 2003). In sum, situational leadership theory provides an opportunity for doctoral learners to understand the complexities of novice leaders' relationships with his or her followers when it comes to establishing effective communication channels.

\subsection{The Path-goal Theory}

This theory relies on the leaders' capacity to help supporters to accomplish common purposes and tasks (Carroll, 2017; Nahavandi, 2006). In this view, if followers accomplish their tasks, the leader will accomplish them as well. This theory is beneficial due to its practical application in any organization. The leader can be supportive in different ways and situations. For example, in the case of new followers and the case of unclear, unstructured, complex or ambiguous tasks. In such cases, leaders should be able to influence his or followers' motivation and willingness to increase goal attainment and path clarification to complete the leadership successfully. In practice, leaders should be able to become the people others want to follow and support.

\subsection{Learning from Experience}

Real leaders must be open to learning from experience. This ability has to do with recognition of the need for new approaches, skills, and strategies when the existing ones no longer work. Also, learning from experience implies being open to the exploration of other alternatives in pursuit of a solution to a problem. Likewise, learning from experience means being able to use effective strategies to acquire new skills (Pitts, 2013; The Jossey-Bass reader, 2003). If leaders make appropriate use of their experiences, they are likely to achieve their goals faster than those who avoid the adverse circumstances or ignore the existing needs. In summary, leaders' open mindedness transforms into practical learning derived from other leaders' and followers' experiences in different situations. Being able to learn from experience then becomes a vital key to successful leadership development plans.

\subsection{Ethics and Morality}

Famous leaders have used ethics and morality to maintain their images among their followers (Clawson, 2006; Hazels, 2015). Ethically leading results in an arduous task because individuals have difficulties in adapting to the principles or codes of the groups to which they belong. Affiliation to a particular team requires strict compliance with and commitment to the internal rules of that group. However, for leaders to reach their vision, they should respond to the specific demands of the group on the ethical functioning expected from all the group members. Morality refers to the determination of what is right and what is wrong (Clawson, 2006 Hazels, 2015). The issue appears to be even more complex than the ethical factor due to the diversity views which try to explain the difference between good behavior and bad behavior. This disparity closely relates to the followers' roles and acts. Determining when they do right things or good things and when they should do them, for example, is truly an elusive issue. However, leaders, mainly novice leaders struggle to make ethics and morality work their way into group projects. In conclusion, adjusting to a group's ideals and their application in the pursuit of shared goals, i.e., common leadership development plans.

\subsection{Inclusiveness, Innovation, and Integrity}

Leaders must be inclusive, innovative, and integral (Gilkey, 1999; Gotsis, \& Grimani, 2016). They must be able to identify those who can be part of their followers. Thus, they should be open to external cooperation and collaboration and be in the position of accepting not rejecting potential members. Likewise, leaders must promote innovation through different tactics: creating an environment conducive to innovation, establishing innovation funds, instilling failure as a way of learning, encouraging the creation of new ideas, and celebrating success (Gilkey, 1999; Gotsis \& Grimani, 2016). The diverse nature of the contexts in which leaders operate serves as a necessary driver of inclusion, 
innovation, and integrity. The three pillars help in optimizing leadership effectiveness, especially when it comes to transforming a vision into reality through a leadership plan.

\section{Identifying Leadership Strengths and Weaknesses}

The interaction with the specific literature on leadership, the doctoral learners, and the insights from written discussion and formative feedback led to the identification of learner's more salient strengths and weaknesses, as the added value from the first doctoral course. Identifying these two personal characteristics contributes to a deeper understanding of students as both people and future leaders. What follows is a description of typical doctoral learners' strengths and weaknesses as individuals and as future leaders in his educational community. The particular academic context for an eventual implementation of the suggested leadership development plan was the Language Department at Universidad de Córdoba in Montería, Colombia, South America. The Language Department offers the English Licentiate Program, which since the inception of new foreign language education programs in the country, has promoted and enhanced foreign language teaching and learning as its overarching goal. This department had minimal experience in educational leadership issues before the current leadership development plan.

\subsection{Strengths}

When thinking of strengths as a leader, the first idea that comes to mind is a sense of organization. Wren (2004) considers four fundamental principles of organization: reciprocal coordination, direct coordination, early coordination, and coordination of a process. Implicit in these core principles is the notion of control, that is, performance control. In this view, the leader's role is translated into "the reciprocal influence of leader on follower and follower on leader in the context of the situation" (p. 310). The different types of organization refer to how leaders and followers work together toward common purposes, mediated by shared interests and common motivation. One important aspect of the organization is the process. As leaders, doctoral learners try to show the pathway to their followers in educational and administrative processes. The key factor is organization in the sense that supportes' efforts receive leadership to accomplish the goals of the Language Department.

In addition to organization, doctoral learners' leadership entails organizational commitment (Farrukh, Wei Ying, \& Abdallah Ahmed, 2016). This commitment is the spontaneous identification of an individual with the organization and the work environment. Educational leaders often share this positive attitude with their fellow teachers who, in turn, try to communicate it to other people in an academic division. If the faculty members, for example, identify themselves with the goals, values, and principles of a University, they strive to maintain the academic and personal connection with the enterprise.

Another leadership strength is a combination of responsibility and trust. These two values are a part of the teleological component of the University institutional project. Responsibility is a must for teachers, students, and the entire academic community. Trust mediates the relationships among the various participants in the academic and administrative process (Vercic \& Zerfass, 2016).

One more leadership strength is another combination of equity, democracy, and justice (Gilkey, 1999). Equity in the Language Department was a priority. The distribution of the academic load among part-time teachers is equitable, according to the candidates' profile and organizational commitment. In this respect, democracy is another practical value, which is alive with the Department. Concerning justice, the foreign language leader assigns academic responsibilities in line with the teachers' job opportunities and work affiliation.

The last pivotal leadership strength is communication management. Such a competency allows for a better understanding of the followers on the part of leaders as well as their effectiveness in using that knowledge to enhance higher performance and better relationships (Vercic \& Zerfass, 2016). Communication management also fosters active commitment within an organization. "Organizational commitment is important for organizational effectiveness in that it enhances employees' desire to remain in an organization, improves their performance... and stimulates their utmost efforts to accomplish the organization's goals..." (Keskes, 2014, p. 37).

\subsection{Weaknesses}

The doctoral learners' weaknesses as leaders are of a personality and affective nature, specifically, non-intellective factors, namely emotional intelligence (Grissette-Banks, 2014; Phipps, Prieto \& Ndinguri, 2014; Singh, 2015). Two main weaknesses illustrate this case. First, the tendency to avoid casual or informal communication (The Jossey-Bass reader, 2003). This conduct is due to leaders' introvert personality and their preference for more formal scenarios and communication channels. A perceived lack of unconscious charisma accompanies such a particular behavior. It appears that informal communication is advantageous concerning new experiences, new information, and 
unexpected issues. Second, the tendency to get depressed and frustrated when things do not turn as expected. Affective problems are truly a constraint because they make it difficult to understand unexpected situations and solve problems (Mathew \& Gupta, 2015).

In summary, there are not perfect leaders. For this reason, designing leadership development plans requires leaders to know themselves as both people and professionals, that is, to know their strengths and weaknesses. "What counts...is self-knowledge about strengths and weaknesses and the ability of leaders to surround themselves with people who have complementary talents ("Perfect Leaders are Figures of Fantasy", 2012).

\section{Designing a Plan for Making the Best Use of Current Strengths and Correcting Weaknesses}

Dealing with strengths and weaknesses requires, first of all, facing the facts about the existence of those strengths and weaknesses. Consequently, to foster strengths and overcome or minimize weaknesses, leaders should design a plan for making the best use of current strengths and correcting weaknesses. This exercise implies assessing their skills and facing the challenge to determine leadership effectiveness in light of core elements such as intelligence, emotional intelligence, key values, and current drive Povah, (2012). Specific plans for reinforcing positive behavior are of enormous importance, namely communication within and organization. One way to cope with communication within an organization is to try to find time for permanent face-to-face communication with them and the use oral language (Holmes \& Parker, 2017). "As such, within the field of educational leadership, ... behavioral integrity and credibility are required in order for motivating language to occur" (p. 70). This organizational strategy is a valuable opportunity to get subordinates to buy into the leader's goals, vision, and next projects. Moreover, due to the close connection of communication to trust, the leader's credibility and integrity are enhanced. Best practices can be instilled when leaders and followers' interaction is constant and active.

Four more ways to maintain effective communication open to followers and the community are organizational transparency, the actual practice of professional convictions, change enhancement, and help from a coach (Delgado \& Mitchell, 2016; Liu, 2010). Organizational transparency and practice of what we preach reinforce credibility and trust, and open up opportunities for change and innovation. Having a coach can help in the decision-making process when consensus is hard to reach or when leaders decide to use autocratic procedures.

The lack of charisma might be a constraint for communication. Society stigmatizes people according to a series of conscious or unconscious charismatic features (Avolio and Yammarino, 2002). The leader can exhibit them by the leader through "social dramatization or ... social reversion" (p. 231). In this sense (and this can be a personality issue), it appears to be that many people do not perceive the doctoral learner's unconscious charisma. Hence, sincere and honest people could help to minimize this weakness (Holmes \& Parker, 2017).

The affective nature of doctoral learners' weaknesses raises the use of emotional intelligence to improve their leadership skills (Grissette-Banks, 2014; Singh, 2015). Current research on the issue showed that emotional intelligence (emotions and mood) play a huge role in both the leadership process and the leader's performance. Phipps, Prieto \& Ndinguri (2014) posited that "emotional intelligence is the ability to recognize one's own feelings as well as the feelings of others, and to use this awareness to motivate oneself and to manage one's emotions and relationships." Therefore, frustration and depression problems can be prevented by centering on the major aspects of the leadership process, such as goals and objectives, significant of work activities, and responsibilities. Constant enthusiasm, optimism, confidence, trust, cooperation, space for flexibility in the decision-making process and change, and maintenance of a sincere identity for the organization (Grissette-Banks, 2014; Singh, 2015) are critical as well. Furthermore, avoiding negative moods and emotions and encouraging positive behavior may contribute to maintaining a healthy environment in the workplace. The success of leadership development plans depends a great deal on the leaders' abilities to design effective strategies for reinforcing existing strengths and transform current weaknesses into new opportunities for continual leadership growth.

\section{Identifying Gaps between the Current Leader and the Future Leader}

In the previous section, some leadership strengths and weaknesses were tackled to find ways to improve doctoral learners' general leadership performance in their workplaces. Now let us focus on leaders' gaps during their doctoral experiences and potential voids as leaders in the future. Leaders can see themselves as transformational and situational leaders who struggle to involve their followers in collaborative work and the achievement of the broad goals of an academic division (i.e., a language department). Their leadership is rooted in some values, such as morality, justice, organizational commitment, innovation, integrity, and commitment to excellence. Even though their image is not that of gifted individuals, they are conscious that inspiring, motivating, and considering people is 
vital in any leadership process (Prasad \& Junni, 2016). Perhaps, charisma, in this case, can be described as conscious (Avolio and Yammarino, 2002) because leaders tend to take their job too seriously and this behavior may cause negative reactions in their followers. However, these leaders consider themselves lifelong learners who are ready to learn and help others learn from both formal and informal experiences (The Jossey-Bass reader 2003).

Doctoral learners' leadership skills remain in the building process until they graduate and start using these skills regardless of all the learning that takes place during a doctoral course. The actual assimilation and application of new knowledge take thought and time. Thus, much of the insights and theoretical assumptions gained from a doctoral course becomes part of a future leader's knowledge repertoire.

A leader of the future must be the type of leader known as an ideal leader, a primal leader, and a high-high leader (Yukl, 2013; The Jossey-bass reader, 2003). Leaders who are prepared to lead in the future must be models, have a clear vision, be able to challenge change and innovation, be able to move others to lead, and celebrate the contribution of others. The primal leader moves people with their brilliant ideas and uses their emotional intelligence to get followers to help him reach a vision. Finally, the leader of the future must be a high-high leader, i.e., an individual who shows concern for both people and productivity. These five high-level leadership dimensions must make the leader of the $21^{\text {st }}$ century.

The leader of the future, too, must be able to combine different forms of charisma - "idealized influence, inspirational leadership, and intellectual stimulation, individual consideration" - (Prasad \& Junni, 2016, p. 1542), power and participation. Likewise, this leader should be able to use coercion, reward, legitimacy, expertise, reference, position power, and personal power. In line with the type of power, the leader of the future should be able to use all kinds of decision procedures: strict decisions, consultation, joint decision, and delegation (Nahavandi, 2006; Yukl, 2013). In conclusion, identifying gaps between the current leader and the leader of the future is a necessary step in designing a personal leadership plan. Doctoral learners' leadership experience is a part of the entire building process, which in turn, helps in defining clear and efficient leadership qualities in the future leader.

\section{Implementing Specific Action Items to Close Gaps between the Current Leader and the Future Leader}

Closing gaps between leaders in the building process and leaders in the future require taking some actions closely related to leaders' recognition of existing strengths and weaknesses which should be maintained or modified to look toward the future. This section describes some action items that can help to achieve that purpose. In closing the gaps above, dealing with emotional intelligence is paramount. The real uncertainty about what truly makes an effective leader leads to resort to alternatives other than transformational, charismatic, and transactional approaches among others (Doe, Ndinguri \& Phipps (2015).

Individuals can cope with and adapt to personal and social problems and solve them (Doe, Ndinguri \& Phipps (2015). In this regard, individuals can respond empathetically, regulate their mood and interpersonal skills, be proficient at dealing with relationships and networks, cope with internal motivation, and develop self-awareness in work-related situations. Accordingly, leaders with a high level of empathy inspire followers and make them feel positive about their leaders and their jobs (Doe, Ndinguri \& Phipps (2015). Leaders with this quality respond positively to organizational effectiveness and organizational commitment. Current research showed that individuals in a positive mood are likely to find solutions to existing problems while those in a bad mood tend to impair problematic situations. According to researchers, interpersonal skills can contribute to problem-solving, more responsible decision-making and a higher level of performance. An internal or intrinsic motivation brings about and fosters organizational commitment. Consequently, followers are prone to influence their work environment. Current research demonstrated that self-aware leaders become more effective managers and benefits from the assessment of others.

These areas are the key to success when individuals are weak due to personality factors. To ameliorate personality-linked factors, open communication, comprising most of the characteristics of emotional intelligence, is critical to finding out more about their followers. This leadership plan includes three major communication-related action items to close the gaps between current leaders as doctoral learners and the future leader (Clawson, 2006).

- Decreasing authority and promoting exchange.

- Using psychological currencies.

- Using communication skills and appropriate language.

Decreasing authority and promoting exchange means that leaders who see their followers as potential allies clarify 
their goals, and can determine what co-workers need and want to be successful in their attempts to reach a vision. Determining what values leaders bestow on followers and the type of exchange established with them is also paramount.

Using psychological currencies is a collective action that leaders perform. These actions can be of different types and intend to set up and maintain a healthy work environment. Some of them are leader-based, and others deal with the employees' professional and personal development. Leaders can inspire with their approach to leadership. They can, for example, be faithful to their vision, show their sense of morality, and their concern with excellence. If they do so, followers can help to achieve their leaders' broader goals and can be more motivated to continue being a part of the organization. The leaders' image concerning visibility, performance, administration, and quality of their relationships is pivotal to gaining the spontaneous support from their followers. In addition to these leader-focused currencies, a leader should concentrate on the supporters' personal and professional needs (Judge and Piccolo, 2004). Giving them training and more job opportunities and instilling ongoing personal and professional development based on their performance can result in a rise in self-esteem and self-appraisal. Obviously, this can be a strong reason for higher organizational commitment.

Using communication skills and appropriate language refers to leaders' practical application of their communication skills. These abilities are deemed to be crucial in any leadership endeavor (Walters \& Norton, 2007). In times of change and innovation, “... being a leader requires more than just technical ability" (p. 16). To inspire and engage followers, leaders need to emphasize for major areas: focus, articulation, modeling, and engagement (Walters and Norton, 2007). In this view, effective leaders know how to identify what they expect from their followers and they, too, know how to accomplish it. Moreover, leaders use such effective strategies to communicate their vision that followers do not forget about it. Likewise, effective leaders rely on examples to communicate with their followers and can maximize their strengths to minimize their weaknesses. Finally, they use effective strategies to make followers fit in the entire leadership process.

In the same vein, social relationships within an organization need mediation through the use of appropriate language. Successful leaders heavily rely on clarity, respect, stimulating expressions, and congruence to communicate their messages to their followers. Clear language guarantees the conveyance, understanding, assimilation, and adoption of the message. An outstanding example is Martin Luther King, Jr. who was able to inspire followers of his time with the powerful statement "I have a dream" (University of Phoenix, 2008). Likewise, leaders' speech should reflect their leadership values so that it can result inspiring and convincing for followers. Respect is an integral element in successful leaders' communications. Mutual respect creates a sense of confidence and a healthy environment within an organization, mainly in times of reform when resistance comes into play. In sum, leaders can resolve conflicts and difficult situations with the constructive mediation of respect (The Jossey-Bass, 2003).

The tone of invitations is another example of how leaders can get his or her followers to join them to reach a vision. They should be persuasive rather than authoritarian. The narratives leaders use to persuade supporters to contain a particular type of language, i.e., the expression of trust and inspiration. ("Narratives, Connections and Social Change", n.d). Finally, congruence and consistency constitute the key to leaders' credibility. In the end, followers expect their leader to keep their promises and agreements. In sum, implementing specific actions items gives current and future leaders a sense of self-knowledge as a significant strength in coping with present and potential voids of the leadership development process.

\section{Establishing a Timeline for Implementing each Action Item in a Plan}

Transformational leadership programs account for deadlines for implementing each action item. Since building leadership is an ongoing process, the leadership actions should not be separated and a particular time for each action is not necessary. Rather, these actions should be part of the entire picture (J. Moon, personal communication, April $15,2008)$. Nevertheless, when leaders need to ensure management, monitoring, and assessment of the process, the plan can take the form of an action research project, which is situational (Cohen, Manion \& Morrison 2011). The purpose is to diagnose a problem in the doctoral learner's own context and attempt to solve it in the same vein. Besides, the project is collaborative because other teachers can work in the data collection process. Modifications made in the course of the situation make the project self-evaluative as well. In the end, the final objective is to improve the leader's behaviors and practice in their work setting.

Cohen, Manion, and Morrison (2011, p. 354-356) come up with eight stages for the efficient implementation of a situational action research project. For the purpose of this article, their taxonomy was reduced to seven. 
- Evaluation and formulation of the situation in practice.

- Determination of the characteristics that truly define doctoral learners' weaknesses.

- Review of the relevant literature.

- Definition of a set of hypotheses or guiding objectives.

- Selection of data collection procedures.

- The project in practice.

- Interpretation and evaluation of the project.

The evaluation and formulation of the situation in practice have to do with doctoral learners' perceptions of their own behaviors and that of the academic collective during a particular period (i.e., four months).

Determination of the characteristics that actually define doctoral learners' weaknesses refers to the consideration of tentative research questions to guide the project.

The review of relevant literature focuses on sources related to transformational leadership, charismatic leadership, situational leadership, and path-way theory to reinforce the implementation of the plan concerning theoretical support.

Efficient implementation of a situational action research project requires the definition of a set of hypotheses or guiding objectives due to its close connection with the doctoral learners' weaknesses (the problem).

In the selection of data collection procedures stage, the leader and a small group of his close coworkers can keep a learning journal (Murgan, 2015) in addition to approach-specific data collection methods. In line with the English Licentiate program accreditation process, authority issues and situations, for example, can be observed and described, using a learning journal. This professional development strategy contains descriptive accounts of the accreditation process, a complete description of the leader's behavior, types of power used, decision styles, and evidence of the use of charismatic strategies to influence the participants in the process.

The project in practice stage requires devoting enough time to collect information about doctoral learners' leadership behavior as well as the analysis of the data gathered.

Finally, the interpretation and evaluation of the project should include discussions in the light of literature related to leadership, and a summary of the project is written for recommendations and arrangements about the transformational leader's overall leadership behavior.

\section{Summary}

This article presented and described a leadership plan derived from the scholar/practitioner/leader model. The ultimate purpose of the roject is to translate course learning into personal leadership development strategies to guarantee that doctoral learners use their leadership skills in their workplaces. The proposed personal leadership development plan implies following six steps associated with the same number of specific tasks as follows. First, theory-based decision- making contributes to the construction of implementable plans, which have practical and significant application in a particular work scenario. The fundamentals of these leadership programs are the central issues of transformational and charismatic leadership, situational leadership, path-way theory, and emotional intelligence. Researchers have shown enough evidence that emotional intelligence in all its dimensions is linked to transformational and charismatic leadership and leadership effectiveness. The trend appears to be that new approaches to the study of leadership should be explored to find out more about, not only cognitive aspects of leadership but also non-cognitive factors that can transform doctoral learners into effective educational leaders.

Second, the identification of strengths and weaknesses to bridge the gap between today's leaders and leaders of the future by the recognition, acceptance, and evaluation of existing strengths and weaknesses. Third, a plan for the practical consideration of strengths and weaknesses allows leaders to make the most of existing strengths and cope with present weaknesses effectively. Fourth, the identification of gaps related to current and potential leaders helps in building solid leadership qualities. Fifth, the implementation of specific action items to close the gaps leads to self-knowledge and awareness of the need for successful intervention. Sixth, the establishment of a timeline gives plans a sense of commitment to and achievement of leadership development goals. Doctoral learners implement personal leadership plans in their particular workplaces in the hope that they will continue to grow personally, professionally, and as leaders of the $21^{\text {st }}$ century. In times of never-ending change and innovation, society needs effective leaders, i.e., those who see themselves as change agents, lifelong learners, and value-driven. (Tichy and 
Devanna, 1990). Toady's society requires individuals who believe in themselves to make change happen and who can get others accomplish such a broader goal.

\section{References}

Al-Husseini, S., Elbeltagi, I., \& Dosa, T. (2013). The Effect of Transformational Leadership on Product and Process Innovation in Higher Education: An Empirical study in Iraq. In L. García, A. Rodríguez-Castellanos, \& J. Barrutia-Guenaga (Eds.), Procedings of the $5^{\text {th }}$ European Conference on Intellectual Capital, pp- 1-10. Plymouth, UK: Academic Conferences and Publishing International Limited Reading. Retrieved from https://www.researchgate.net/publication/288141820_The_Effect_of_Transformational_Leadership_on_Produc t_and_Process_Innovation_in_Higher_Education_An_Empirical_Study_in_Iraq

Allen, K. E. (2002). The purpose of scholarship, redefining meaning for student affairs. NASPA Journal, 39(2), 147-157. https://doi.org/10.2202/0027-6014.1167

Avolio, B. J., \& Yammarino, F. J. (2002). Transformational and charismatic leadership: the road ahead. New York, NY: Elsevier.

Beatty, C. C. (2014). Exploring the leadership identity development of students of color at a selective liberal arts college. Available from ProQuest Dissertations \& Theses Global. (1621575553). Retrieved from https://search.proquest.com/docview/1621575553?accountid=458

Buss, R., Zambo, R., Zambo, D., \& Williams, T. (2014). Developing researching professionals in an EdD program: From learners and leaders to scholarly and influential practitioners. Higher Education, Skills and Work-based Learning, 4, 137-160. https://doi.org/10.1108/HESWBL-11-2013-0022

Carroll, B. J. (2017). Participatory action research: Identifying perceptions of leadership style and the use of path-goal leadership theory among child protection services social workers (Doctoral Dissertation, University of Capella, 2017). Retrieved from ProQuest database.

Clawson, J. B. (2006). Level three leadership: Getting below the surface (3d ed. ). Upper Saddle River, NJ: Pearson.

Cohen, M., Manion, L., \& Morrison, K. (2011). Research methods in education (7 ${ }^{\text {th }}$ ed.). London, England: Routledge.

Delgado, C., \& Mitchell, M. M. (2016). A survey of current valued academic leadership qualities in nursing. Nursing Education Perspectives, 37(1), 10-15. http://dx.doi.org/10.5480/14-1496

Doctor of Education in Educational Leadership with a specialization in Curriculum and Instruction: Learning Outcomes. (2012). Retrieved from: http:/www.phoenix.edu/content/dam/altcloud/programs/outcomes/EDD-CI-Assessment-110712.pdf

Doe, R., Ndinguri, E., \& Phipps, S. T. A. (2015). Emotional intelligence: the link to success and failure of leadership. Academy of Educational Leadership Journal, 19(3), 105-114.

Farrukh, M., Wei Ying, C., Abdallah Ahmed, N. O. (2016). Organizational commitment: Does religiosity matter? Cogent Business \& Management, 3(1). http://dx.doi.org/10.1080/23311975.2016.1239300

Gilkey, R. W. (1999). The 21st century health care leader. San Francisco, CA: Jossey-Bass.

Gotsis, G., \& Gimani, K. (2016) Diversity as an aspect of effective leadership: integrating and moving forward. Leadership \& Organization Development Journal,. $37(2), \quad$ 241-264. http://dx.doi.org/10.1108/LODJ-06-2014-0107

Graeff, C. L. (1997). Evolution of situational leadership theory: A critical review. Leadership Quarterly, 8(2), 153-170. https://doi.org/10.1016/S1048-9843(97)90014-X

Grissette-Banks, M. (2014). The emotional intelligence of successful african american women leaders. Available from ProQuest Dissertations \& Theses Global. (1494127478). Retrieved from https://search.proquest.com/docview/1494127478? accountid $=458$.

Hatfield, L. J. (2015). The scholarship of student affairs professionals: Effective writing strategies and scholarly identity formation explored through a coaching model. Available from ProQuest Dissertations \& Theses Global. Retrieved from https://search.proquest.com/docview/1707355194? accountid=35812

Hazels, T. (2015). Ethics and morality: What should be taught in business law? Academy of Educational Leadership Journal, 19(2), 77-89. 
Holmes, W. T., \& Parker, M. A. (2017). Communication: Empirically testing behavioral integrity and credibility as antecedents for the effective implementation of motivating language. International Journal of Business Communication, 54(1), 70-82. http://dx.doi.org/10.1177/2329488416675450

Keskes, I. (2014). Relationship between leadership styles and dimensions of employee organizational commitment: A critical review and discussion of future directions. Intangible Capital, 10(1), 26-51. http://dx.doi.org/10.3926/ic.476

Liu, C. (2010). Leadership: Qualities, skills, and efforts. Interbeing, 4(2), 19-25.

Mathew, M., \& Gupta, K. S. (2015). Transformational leadership: Emotional intelligence. SCMS Journal of Indian Management, 12(2), 75-89.

Mitra, R. (2017). Communicative tensions of meaningful work: The case of sustainability practitioners. Human relations, 70, 594-616. http://dx.doi.org/10.1177/0018726716663288

Mulla, Z. R., \& Krishnan, V. R. (2011). Transformational Leadership: Do the leader's morals matter and do the follower's morals change? Journal of Human Values, 17(2) 129-143. http://dx.doi.org/10.1177/097168581101700203.

Murgan, M. G. (2015). A Critical analysis of the techniques for data gathering in legal research. Journal of Social Sciences and Humanities, 1(3), 266-274.

Nahavandi, A. (2006). The Art and Science of Leadership. Upper Saddle River, NJ: Pearson. Narratives, Connections and Social Change. (n.d). Retrieved from http://roar.uel.ac.uk/3388/1/2012_Squire_Narratives-connections.pdf

Martin Hellawell. (2012). Perfect leaders are figures of fantasy: What counts is knowing your strengths and weaknesses. Strategic Direction, 28(5), 22-25. http://dx.doi.org/10.1108/02580541211222979

Phipps, S. T. A., Prieto, L. C., \& Ndinguri, E. N. (2014). Emotional intelligence: Is it necessary for leader development? Journal of Leadership, Accountability and Ethics, 11(1), 73-89.

Pitts, A. (2013). Learning from experience. Nursing Standard, 17(21), 58-59. http://dx.doi.org/10.7748/ns.17.21.58.s58.

Pochron, S. (2009). The Requisite Organization of Integral Leadership Part 1: An Integrative Approach. Integral Leadership Review, 9(3), 1-11.

Povah, L. (2012). Assessing leaders for the future. Industrial and Commercial Training, 44, 250-258. http://dx.doi.org/10.1108/00197851211244988

Prasad, B., \& Junni, P. (2016). CEO transformational and transactional leadership and organizational innovation: The moderating role of environmental dynamism. Management Decision, 54, 1542-1568, http://dx.doi.org/10.1108/MD-11-2014-0651

Singh, P. (2015). Leaders lacking emotional intelligence: Towards A theory of tobephobic leaders. Journal of Applied Business Research, 31(3), 1179-n/a. https://doi.org/10.19030/jabr.v31i3.9232

Terry, H., \& Liller, K. (2014). The Doctoral Student Leadership Institute: Learning to Lead for the Future. Journal of Leadership Education, 13(1), 126-135. http://dx.doi.org/10.12806/V13/I1/I2

Jossey-Bass \& Margaret Grogan. (2003). The Jossey-Bass reader on educational leadership. (2003). San Francisco, CA: Jossey-Bass.

Thompson, G., \& Glasø, L. (2015). Situational leadership theory: a test from three perspectives . Leadership \& Organization Development Journal, 36, 527-544. http://dx.doi.org/10.1108/LODJ-10-2013-0130

Tichy, N. M., \& Devanna, M. A. (1990). The transformational leader. New York, NY: Jon Wiley \& Sons.

University of Phoenix. (2008). Week two lecture. Retrieved May 4, 2008, from University of Phoenix, Week Four rEsource Web site.

University of Phoenix. (2012). Doctor of Education in Educational Leadership with a specialization in Curriculum and Instruction $(\mathrm{EdD} / \mathrm{CI})$ : Learning outcomes. Retrieve from http://www.phoenix.edu/content/dam/altcloud/programs/outcomes/EDD-CI-Assessment-110712.pdf

Vercic, D., \& Zerfass, A. (2016). A comparative excellence framework for communication management. Journal of Communication Management, 20, 270-288. http://dx.doi.org/10.1108/JCOM-11-2015-0087 
Walters, D., \& Norton, D. (2007). Leadership Communication - the astraZeneca way. Retrieved from http://www.synopsisonline.com/wordpress/wp-content/uploads/2011/04/Leadership-communication-the-AstraZ eneca-way-January-2008.pdf

Wren, D. (2005). The history of management thought (5th ed.). New York, NY: John Wiley and Sons.

Yukl, G. (2013). Leadership in organizations (6th ed.). Upper saddle River, NJ: Pearson. 